\title{
MORÁLNÍ URČENÍ VU゚LE U IMMANUELA KANTA
}

\section{Jakub Sirovátka}

Kantova etika je někdy kritizována za př́lišný rigorismus, formalismus či abstraktnost. Je jí vytýkán prŕlišný dưraz na povinnost, na dodržení formálního mravního zákona, který platí bezprostředně a kategoricky. Kritikové namítají, že Kant nebere ve své mravní teorii ohled na lidskou přirozenost, která je hluboce spojena s cítěním a s touhou být št’astným. ${ }^{1}$ Př́liš prý hledí na dodržování abstraktního principu, a nezohledňuje tak konkrétní danou situaci. ${ }^{2}$ Tyto a podobné výtky míŕí na jeden z centrálních bodů Kantovy morální filosofie: na problematiku, jak a čím musí být určena lidská vůle v mravním ohledu. Účelem tohoto př́spěvku je zkoumání právě této otázky. Je mravní zákon skutečně tím jediným a výhradním faktorem mravního určení vůle? Nejdříve se podíváme na Kantovu „konečnou“ pozici v jeho kritickém díle. Zároveň se budeme věnovat i několika pasážím ze spisu Náboženství v hranicích pouhého rozumu, ve kterých se Kant $\mathrm{k}$ této problematice vyjadřuje a které svým obsahovým zaměřením patří do kritického projektu. V druhém kroku zasadíme Kantovu kritickou pozici ohledně morálního určení vůle do širšího kontextu jeho díla. Zohledníme přitom především Kantovu Přednášku o etice a Reflexe, které jednoznačné kritické stanovisko poněkud

1 Některé novější publikace se snaží tento dojem vyvrátit a zdůrazňují pozitivní roli „emocí“, citu apod. v Kantově myšlení. Srv. např. D. Williamson, Kant's Theory of Emotion. Emotional Universalism, New York 2015; A. Cohen (vyd.), Kant on Emotion and Value, New York 2014.

2 Zástupně za mnohé kritiky je možno jmenovat výhrady vůči Kantově etice vznášené z pozice etiky péče. Virginia Heldová kupříkladu vytýká Kantovu konceptu (ale i jiným etickým koncepcím), že proti sobě staví „individuální ego“a „universální principy“, že „zavazující morální nárok konkrétní druhé osoby“ podřizuje požadavku zobecnitelnosti morálních soudů. Srv. V. Held, Etika péče. Osobní, politická a globální, přel. P. Urban, Praha 2015, str. 25 a 161. Zároveň je ve jménu autonomie vyloučen vliv emocí: „Ideál rozumové kontroly od nás žádá, abychom ve snaze o dosažení autonomie vyloučili vliv emocí. Mezi takto vyloučené emoce by ale kromě těch, které ohrožují morálku, spadaly i morální emoce empatie, citlivosti a vzájemného vztahu. Ideál autonomie jako nadvlády rozumu se tak ukazuje jako problematický.“(Tamt., str. 102.) 
problematizují. Ve své Přednášce o etice, jejíž text se vztahuje k přednáškám prosloveným pravděpodobně v období mezi roky 1770 až 1780 , Kant provádí mnoho ze svých stěžejních rozlišení a rozpracovává pozice, které v zásadním slova smyslu podrží i ve svých kritických spisech, což platí i o jeho etice. Věnovat se tedy budeme jak spisům publikovaným za Kantova života, tak textům z jeho pozůstalosti. To nám umožní na jedné straně sledovat cestu, po níž Kant ke své zralé kritické pozici došel, na druhé straně však uvidíme, že tato konečná pozice vykazuje jistou nejednoznačnost, která je opět přístupná různým interpretacím. Na závěr pak naznačíme, jak by mohla vypadat konsistentní interpretace, která by i přes jistou nevyjasněnost ukázala, v čem spočívá jádro Kantovy pozice.

\section{Kritická pozice: morální určení vůle výhradně skrze mravní zákon}

Kantova zásadní pozice ohledně morálního učení lidské vůle spočívá v náhledu, že abychom mohli hovořit o čistém mravním určení, musí vůli určovat výhradně objektivní a bezprostředně platný, formální mravní zákon. V Kritice praktického rozumu Kant jasně píše: „Jenom formální zákon, tj. takový zákon, který rozumu nepředpisuje nic víc než formu jeho všeobecného zákonodárství jako nejvyšší podmínku maxim, může být apriorní pohnutkou praktického rozumu. “3 Mravní zákon musí být nejen objektivní pohnutkou (Bestimmungsgrund) vůle, nýbrž musí být i subjektivní pružinou (Triebfeder). Pružinou Kant rozumí „subjektivní základ žádosti“. Jako taková je tedy pružina spojena se subjektivními účely. Pohnutka oproti tomu znamená „objektivní základ chtění“ spojený s objektivními účely, ,jež platí pro každou rozumnou bytost". ${ }^{4}$ I v pozdějším spisu Náboženství v hranicích pouhého rozumu, který úzce navazuje na kritický projekt a stále stojí v jeho kontextu, klade Kant důraz na „přísné“ vymezení etického: „Etice však velmi záleží na tom, aby se vyhnula, pokud je to možné, všemu, co je morálně neutrální, jak v jednání (adiaphora), tak v lidských charakterech, protože při takové dvojznačnosti je nebezpečí, že maximy ztratí svou určitost a stálost. Zastánci tohoto striktního způsobu myšlení se obvykle nazývají rigoristé (toto

3 I. Kant, Kritika praktického rozumu, přel. J. Loužil, Praha 1996, str. 110; Kritik der praktischen Vernunft, in: Werke in zehn Bänden, vyd. W. Weischedel, VI: Schriften zur Ethik und Religionsphilosophie, Darmstadt 1983, A 113.

4 Srv. I. Kant, Základy metafyziky mravi̊, přel. L. Menzel, Praha 2014², str. 46 n.; Grundlegung zur Metaphysik der Sitten, in: Werke in zehn Bänden, VI, BA 63. 
slovo v sobě má zahrnovat výtku, ale ve skutečnosti je chválou) a jejich odpůrci latitudinaristé."5 Tato pasáž je obsažena v první části Kantova spisu, a to v rámci pojednání o radikálním zlu v lidské přirozenosti. „Rigoristické pojetí“ etiky obsahuje podle Kanta důležitý poznatek: „Svoboda vůle je zcela zvláštní povahy v tom, že pružina [Triebfeder] může určit vůli k jednání, jen nakolik člověk danou pružinu pojal do své maximy (učinil ji obecným pravidlem, podle něhož chce jednat). Jedině tak může pružina, at' je jakákoli, koexistovat s absolutní spontánností vůle (tj. svobody). Ale morální zákon je v soudu rozumu sám o sobě pružinou, a kdo si činí morální zákon svou maximou, je morálně dobrý. “6 Kant zde rozlišuje na jedné straně objektivní, bezprostředně, a priori platící mravní zákon, který si rozum sám ukládá a který musí člověk poslouchat. Na druhé straně se hovoří o tzv. „pružině“, tedy subjektivní „síle“, jež motivuje vưli, aby skutečně v konkrétním jednání dokázala realizovat to, co jí ukládá mravní zákon. Chvályhodný rigorismus by pak spočíval v náhledu, že mravní zákon dokáže tak silně určovat vůli, že je zároveň její pružinou, tedy že vůle nepotřebuje žádných dalších pružin. Mravní zákon tedy v sobě obsahuje veškerou mravní - i subjektivní - motivaci. Vzápětí však Kant zdůrazňuje, že plnění etických povinností nemůže být spojeno s ,úzkostně schoulenou a skleslou“ myslí: „Otrocké smýšlení nikdy nemůže být bez skryté nenávisti k zákonu, a srdce plnící radostně povinnost (nikoli samolibé uznávání zákona) je známkou opravdovosti ctnostného smýšlení." ${ }^{7}$ Pevné rozhodnutí konat dobro spojené s pokrokem v dobru vyvolává ,radostný stav mysli, bez něhož nikdy nemáme jistotu, že jsme skutečně získali lásku k dobru, tj. že jsme ji pojali do své maximy“. ${ }^{8}$ Již tato poznámka, která byla odpovědí na Schillerovu výtku, že mravní smýšlení je spojeno se skrupulózní a zachmuřenou myslí, ukazuje na dilema, jež je v Kantově etickém konceptu virulentní: totiž otázka vztahu objektivního mravního zákona a subjektivní „pružiny“, která nám pomáhá mravně přikázané ve svém životě uskutečňovat.

Zároveň v Základech metafyziky mravů Kant zdůrazňuje, že mravní zákony a mravní pojmy nesmí být založeny na (empirické) antropologii,

5 I. Kant, Náboženství v hranicích pouhého rozumu, přel. K. Šprunk, Praha 2013, str. 64; Religion innerhalb der Grenzen der bloßen Vernunft, in: Werke in zehn Bänden, VII: Schriften zur Ethik und Religionsphilosophie, Darmstadt 1983, BA 9.

6 I. Kant, Náboženství v hranicích pouhého rozumu, str. 66; Religion innerhalb der Grenzen der bloßen Vernunft, B 12.

7 Tamt., str. 65 n.; B $11 \mathrm{n}$.

8 Tamt., str. 66; B 12. 
nýbrž výlučně na rozumu, nebot’ mají platit pro všechny rozumné bytosti, a být tak všeobecným mravním zákonem. Celou morálku je nutno vyložit „,nezávisle“ na antropologii ,,jako čistou filosofii, tj. jako metafyziku““. ${ }^{9}$ Avšak k , užití“ morálky na člověka je antropologie vyžadována. ${ }^{10}$ Tuto pozici zachovává Kant i ve své pozdější Metafyzice mravů: Metafyzika mravů jako „systém poznatků a priori z pouhých pojmů“ nesmí být sice na antropologii založena, ale musí být na ni aplikována. ${ }^{11}$ Nejednoznačnost Kantovy pozice dokumentuje jiná pasáž ze Základů, která navozuje dojem, že „empirické“ je problematické nejen pro určení principu mravnosti, nýbrž i pro „čistotu mravů samých“: „Všechno tedy, co je empirické, je nejen zcela nezpůsobilé být prŕídavkem k principu mravnosti, nýbrž je i nanejvýš škodlivé čistotě mravů samých, u nichž vlastní a nad jakoukoli cenu povznesená hodnota naprosto dobré vůle spočívá právě v tom, že princip jednání je prost všech vlivů nahodilých důvodů, které kdy může poskytnout zkušenost. Nelze ani dost důrazně a dost často varovat před takovou nedbalostí, ba nízkým způsobem myšlení při vyhledávání tohoto principu mezi empirickými pohnutkami a zákony..."12 S „rigoristickým“ určením nejvyššího mravního zákona souvisí nakonec i to, že zdůvodnění mravnosti nepředpokládá ani antropologii, ale ani náboženství. Kantova „konečná“ pozice ohledně vztahu etiky a náboženství je asi nejznáměji vyjádřena v pasáži ve spisu Náboženství v hranicích pouhého rozumu: „Morálka se zakládá na pojetí člověka jako bytosti, která je svobodná, a právě proto váže svým rozumem sama sebe na nepodmíněné zákony. Morálka tedy nepotřebuje ani ideu jiné bytosti nad člověkem $\mathrm{k}$ tomu, aby poznával svou povinnost, ani jinou pružinu [Triebfeder] než sám zákon, aby svou povinnost plnil.“"13 Opět je zde zdůrazněno, že mravní zákon má jako jediný nejen určovat lidskou vůli, ale má být zároveň i její jedinou pružinou.

9 I. Kant, Základy metafyziky mravi̊, str. 31; Grundlegung zur Metaphysik der Sitten, BA 35.

10 Srv. tamt.

11 Srv. I. Kant, Metaphysik der Sitten. Rechtslehre, in: Werke in zehn Bänden, VII, AB 11.

12 I. Kant, Základy metafyziky mravů, str. 45; Grundlegung zur Metaphysik der Sitten, BA 61.

13 I. Kant, Náboženství v hranicích pouhého rozumu, str. 49; Religion innerhalb der Grenzen der bloßen Vernunft, BA III. 


\section{Blaženost a náboženství jako pružiny vůle?}

Kantova na první pohled jasná charakterizace mravního zákona a jeho vlivu na vůli v kritické filosofii však není tak jednoznačná, jak by se z výše uvedených citací zdálo. Již v kritických spisech samých lze vystopovat jistou problematičnost otázky vlivu objektivního mravního zákona na subjektivní vůli. Lidskou vůli má na jedné straně určovat jedině mravní zákon, na druhé straně je však zřejmé, že každá vưle potřebuje ke své aktivaci nějaký objekt. V Kantově morálním systému zastává tuto funkci „mravního“ objektu pojem nejvyššího dobra. Mravní zákon vůli přikazuje, aby usilovala o uskutečnění nejvyššího dobra ve smyslu syntézy mravnosti a blaženosti. A tu se ukazuje, že nejvyšší dobro ve spojení s mravním zákonem hraje nejen roli objektu, nýbrž překvapivě i roli pohnutky: „Rozumí se však samo sebou, že je-li v pojmu nejvyššího dobra mravní zákon jako nejvyšší podmínka již spoluobsažen, potom není nejvyšší dobro pouze objektem, nýbrž také jeho pojmem, a představa jeho existence, možné díky našemu praktickému rozumu, je zároveň pohnutkou čisté vůle." 14 Jedná se u této pasáže o jakýsi „cizorodý" "prvek, který se vymyká zásadnímu vymezení mravního určení vůle v Kritice praktického rozumu a který se zdá být pozůstatkem jisté nevyjasněnosti z kapitoly $O$ ideálu nejvyššiho dobra z Kritiky čistého rozumu? V Kritice čistého rozumu totiž některé pasáže vzbuzují dojem, že představa Boha a s ním spojená představa ,ř́íše milosti“ tvoří představy, jež nutně potřebujeme jako pružiny pro vedení morálního života. Nejdříve Kant předjímá svou pozdější nauku o postulátech, když zdůrazňuje, že „Bůh a př́šstí život“ tvoří „dva předpoklady, jež nelze odloučit od povinnosti““. Poté dodává: „Proto také každý člověk považuje morální zákony za přikázání, jimiž by však nemohly být, kdyby se svým pravidlem a priori nespojovaly přiměřené následky, a neobsahovaly by tedy př́sliby a hrozby. "15 Není však jasné, jak máme tyto prísliby a hrozby chápat: zda jako určení vůle či pouze jako představy, které nám mají dopomáhat konat to, $\mathrm{k}$ čemu jsme mravním zákonem zavázáni. Zdá se, že Kant zde inklinuje k pojetí, že náboženské představy - oproti pozici v Kritice praktického rozumu - plní funkci subjektivní mravní pružiny: „Bez Boha tedy a bez světa, jenž je pro nás nyní

14 I. Kant, Kritika praktického rozumu, str. 188; Kritik der praktischen Vernunft, in: Werke in zehn Bänden, VI, A 197.

15 I. Kant, Kritika čistého rozumu, přel. J. Loužil ve spolupráci s J. Chotašem a I. Chvatíkem, Praha 2001, str. 482; Kritik der reinen Vernunft, in: Werke in zehn Bänden, IV/2, Darmstadt 1983, B 839. 
neviditelný, ale v nějž doufáme, jsou nádherné ideje mravnosti sice předměty souhlasu a obdivu, nikoli však pružinami předsevzetí a konání, protože nenaplňují celý účel, který je pro každou rozumnou bytost přirozený a právě tímto čistým rozumem a priori určený a nutný." 16

Jak správně zdůrazňuje Maximilian Forschner, kterým se zde nechávám inspirovat, i v Náboženství $v$ hranicích pouhého rozumu nacházíme zásadní spojení mravního zákona s nejvyšším dobrem, jehož absence by mohla mít za následek náhled neuskutečnitelnosti toho, co mravní zákon přikazuje. ${ }^{17}$ Možná neuskutečnitelnost povinovaného by však prokázala sám mravní zákon jako iluzivní: „Protože pak podporování nejvyššího dobra, které toto spojení ve svém pojmu obsahuje, je a priori nutným objektem naší vůle a souvisí nerozlučně s morálním zákonem, musí nemožnost toho prvního dokazovat také nesprávnost toho druhého. Je-li tedy nejvyšší dobro podle praktických pravidel nemožné, musí být i morální zákon, který je přikazuje podporovat, fantastický a zaměřený k prázdným, imaginárním účelům, a tudíž o sobě falešný." 18 Absence nejvyššího dobra jako pojmu, který obsahově určuje spojení mravnosti a blaženosti, a jako účelu, který vyplývá „Z morálky“, by znamenala „překážku pro morální rozhodování“.19 Idea nejvyššího dobra „na světě, pro jehož možnost musíme postulovat vyšší, morální, nejvýš svatou a všemohoucí Bytost, která jedině může spojovat oba prvky tohoto nejvyššího dobra“, totiž „odpovídá naší př́irozené potřebě myslet pro všechno naše jednání či upuštění od jednání vzaté jako celek nějaký konečný účel, který může být odůvodněn rozu-

16 I. Kant, Kritika čistého rozumu, str. 483; Kritik der reinen Vernunft, B 841. Srv. k tomu J. Sirovátka, Die moralische ,Endabsicht' der Vernunft. Zum, Kanon der reinen Vernunft', in: N. Fischer (vyd.), Kants Grundlegung einer kritischen Metaphysik. Einführung in die Kritik der reinen Vernunft, Hamburg 2010, str. 387-389.

17 Srv. k tomu M. Forschner, Das Ideal des moralischen Glaubens. Religionsphilosophie in Kants Reflexionen, in: F. Ricken - F. Marty (vyd.), Kant über Religion, Stuttgart - Berlin - Köln 1992, str. 84.

18 I. Kant, Kritika praktického rozumu, str. 195 n.; Kritik der praktischen Vernunft, A 205.

19 Srv. M. Forschner, Das Ideal des moralischen Glaubens. Religionsphilosophie in Kants Reflexionen, str. 84: „Unklar bleibt, in welcher Hinsicht ,die moralische Entschließung' den Kerngedanken des Vernunftglaubens bedarf und in welcher nicht. Eine klare Antwort wäre wohl in der Richtung zu suchen, daß die Ausbildung und Anerkennung einer Position der Moralität, wie Kant sie versteht, keinerlei Glaubensprämissen voraussetzt, daß aber auf dem Boden und unter der Perspektive dieses Standpunktes ein vernünftiges Selbst- und Weltverhältnis die von Kant genannten Glaubenssätze notwendig einschließt.“ 
mem“. ${ }^{20}$ Jakkoli Kant trvá na tom, že vůli má v mravním ohledu určovat výlučně objektivní mravní zákon, přesto na druhé straně připouští, že vůle potřebuje pro plnění povinovaného à la longue jak subjektivní pružinu, tak i účel (nejvyšší dobro), který se snaží realizovat.

\section{Morální určení vůle v kontextu Přednášky o etice a Reflexí}

Nejednoznačnost Kantovy pozice se ukáže $v$ ještě ostřejším světle, pokud vezmeme v potaz jeho texty z pozůstalosti, především jeho přednášky $O$ etice a Reflexe k morální filosofii a filosofii náboženství. ${ }^{21}$

Morální teorie sice podle Kantových slov není teorií o tom, jak se učinit št’astným, ${ }^{22}$ takže v momentu mravního jednání nemáme brát ohled na vlastní štěstí, neznamená to však, že se o své štěstí nemáme starat vůbec, a to ani z mravní perspektivy. Nebot' existuje i neprímá povinnost starat se o své štěstí: Rozlišení principu blaženosti a principu mravnosti totiž nestaví tyto principy proti sobě a ,čistý rozum nechce, abychom se vzdali všech nároků na blaženost, nýbrž pouze abychom na ni nebrali vůbec žádný ohled tam, kde je řeč o povinnosti. V jistém ohledu může být dokonce naší povinností pečovat o svou blaženost; zčásti proto, že blaženost ... obsahuje prostředky k splnění naší povinnosti, zčásti proto, že její nedostatek ... s sebou nese pokušení, abychom svou povinnost porušili““. ${ }^{23}$ Rozhodující je, že hledané štěstí musí mít své opodstatnění $\mathrm{v}$,důvodu a priori““, a být tedy v souladu s moralitou. ${ }^{24}$ Ani mravně charakterní člověk nedokáže jako konečná a potřebná bytost odložit svoji touhu po štěstí a samo vědomí, že je hoden být št’astným, ho ještě

20 I. Kant, Náboženství v hranicích pouhého rozumu, str. 51; Religion innerhalb der Grenzen der bloßen Vernunft, BA VII n.

21 Srv. k tomu I. Kant, Eine Vorlesung über Ethik, vyd. P. Menzer, Berlin 1924; I. Kant, Vorlesung zur Moralphilosophie, vyd. W. Stark, Berlin - New York 2004; důležitá kapitola „O nejvyšším principu morálky“ vyšla v překladu J. Chotaše in: J. Chotaš - J. Karásek (vyd.), Kantův kategorický imperativ, Praha 2005, str. 136-141; I. Kant, Reflexionen, in: Kant's gesammelte Schriften $(=$ AA), XIX, Kant's handschriftlicher Nachlaß. Moralphilosophie, Rechtsphilosophie und Religionsphilosophie, vyd. Preußische Akademie der Wissenschaften, Berlin - Leipzig 1934.

22 Srv. I. Kant, Kritika praktického rozumu, str. 222; Kritik der praktischen Vernunft, A 234.

23 Tamt., str. 159; A $166 \mathrm{n}$.

24 Srv. I. Kant, Reflexionen, 7202, in: AA XIX, str. 277: ,,sondern Glückseligkeit muß von einem Grunde a priori, den die Vernunft billigt, herkommen.“ 
št’astným nečiní. Na jedné straně totiž dotyčný člověk nikdy nedokáže plně posoudit svou mravnost, čistotu své mravní motivace, ${ }^{25}$ na druhé straně potřebuje i ten nejmravnější člověk podle Kanta alespoň naději na dosažení blaženosti - když ne v tomto světě, tak po smrti. A tato „vyhlídka“ prredstavuje podle Přednášky o etice (a tudíž v protikladu k pozici zastávané v úvodu k Náboženství v hranicích pouhého rozumu) dokonce „největší pružinu“: ,ideál svatosti“ chápaný jako „,být hoden blaženosti“ vykazuje nejen ,největší mravní dokonalost“", nýbrž „tento ideál má také největší pružinu, a to je blaženost, ale ne na tomto světě“. ${ }^{26}$

Na jiném místě se však nehovoří o pružině, nýbrž o tom, že blaženost „,není důvodem, není principem morality, ale jejím nutným doplňkem“27 - to je pozice, která zůstává v platnosti i pro kritický „,projekt". Smyslové popudy, ke kterým blaženost rovněž patří, nemají hrát roli pohnutky vůle, nýbrž mají působit jako subsidiaria motiva. ${ }^{28}$ Nejčistší ideál mravnosti (který je podle Kanta shodný s křest'anskou představou mravnosti, která oproti „„skolám starých“ - oproti epikurejcům, stoikům, platonikům atd. - představuje mravnost ve své nejvyšší čistotě a v souladu s antropologií) je spojen s pojmem nejvyššího dobra, z něhož plynou postuláty existence Boha a nesmrtelnosti duše.

V jiných pasážích však Kant opět navozuje dojem, že náboženství jako naděje na blaženost po smrti je mravní pružinou: „Bez náboženství je všechna závaznost bez pružiny. “29 A ve svých Reflexích Kant píše, že „bez náboženství by morálka neměla pružiny, které musí být všechny odvozeny od blaženosti.“ Dokonce zde říká: „Morální příkazy musí být

25 Srv. I. Kant, Kritika čistého rozumu, str. 347; Kritik der reinen Vernunft B 579: „Vlastní moralita jednání (odměna i vina) - dokonce i moralita našeho vlastního chování - nám proto zůstává zcela skryta. Otázky naší odpovědnosti se mohou týkat jen empirického charakteru. Kolik z toho je čistým účinkem svobody a kolik je třeba připsat na vrub pouhé přírodě a nezaviněné vadě temperamentu, nebo jeho št'astné podobě (merito fortunae), nemůže nikdo zjistit, a proto ani zcela spravedlivě posoudit."

26 I. Kant, Eine Vorlesung über Ethik, str. 13: „Nicht allein die Würdigkeit der Glückseligkeit hat in diesem Ideal [das Ideal der Heiligkeit] die größte sittliche Vollkommenheit, sondern dieses Ideal hat auch die größte Triebfeder, und das ist die Glückseligkeit, aber nicht in dieser Welt.“

27 Tamt., str. 97: „Die Glückseligkeit ist kein Grund, kein Principium der Moralität, aber ein notwendiges Corrollarium derselben.“

28 Srv. tamt., str. 95.

29 Tamt., str. 102: „Ohne Religion ist alle Verbindlichkeit ohne Triebfeder.“ 
doprovázeny př́sliby nebo hrozbami. “30 Kant tedy i ve svých Reflexích kolísá v názoru, jak by měl vztah mravnosti a blaženosti, spojené s náboženstvím, vypadat.

Tím se ale stává zřejmé to, co platí i pro kritickou filosofii: Bez naděje na dosažení blaženosti nelze následovat ideál mravnosti. Dủležité je přitom Kantovo upozornění, že se musí jednat o naději, nejde o nárok na blaženost (nikdy totiž skutečně nevíme, zda jsme blaženosti hodni či do jaké míry). ${ }^{31} \mathrm{~A}$ i když zůstává v platnosti, že morálka žádné náboženství nepředpokládá, přesto se náboženství přinášející vyhlídku na posmrtnou blaženost stává integrální částí Kantova etického konceptu. I pro věřícího platí, že nedělá něco z toho důvodu, že to chce Bůh, nýbrž protože je to dobré, a jako dobré je to chtěné i Bohem. ${ }^{32} \mathrm{~S}$ náboženstvím se tedy v Kantově systému mravnosti opět dostává do popředí fenomén štěstí, které však vždy musí stát pod podmínkou mravnosti. Ačkoliv morálka náboženství z dobrých důvodů nepředpokládá, hraje náboženství v Kantově konceptu nezastupitelnou roli. I v kritické filosofii lze najít místa, v nichž náboženství hraje úlohu - když už ne stejnou, tak velmi podobnou - subjektivní pružiny. V Metafyzice mravi̊ hovoří Kant o v určitém smyslu antropologicky „nutné“ představě Boha v souvislosti s mravní povinností: „My si totiž povinnost (morální donucování) nedokážeme zřejmě jinak názorně představit než pouze s představou někoho jiného a jeho vůle (přičemž všeobecně zákonodárný rozum je jen jeho mluvčím), totiž Boha."33 Tato pozice z roku 1797 se však velmi podobá náhledům vyjádřeným $\mathrm{v}$ Reflexích, které pocházejí pravděpodobně z období okolo roku 1780 a pozdějšího: „Mravní zákony mají ovšem principium obligandi [princip závaznosti] v sobě, ale nezavazují bez náboženství, protože ze své podstaty neobsahují přislíbení

30 I. Kant, Reflexionen, 6858, in: AA XIX, str. 181: „Es ist wahr: ohne Religion würde die moral keine triebfedern haben, die alle von der Glückseligkeit müssen hergenommen seyn. Die moralischen Gebothe müssen eine Verheißung oder Drohung bey sich führen.“

31 Srv. I. Kant, Reflexionen, 8085, in: AA XIX, str. 629: „Es ist also nicht unsre eigene Gerechtigkeit, sondern fremdes Verdienst, was zu unsrer Seeligkeit erfodert wird.“

32 Srv. I. Kant, Eine Vorlesung über Ethik, str. 28: „Es muß also eine Handlung geschehen, nicht deswegen, weil sie Gott will, sondern weil sie an sich selbst rechtschaffen oder gut ist; und weil sie so ist, so will sie Gott und verlangt sie von uns.“

33 I. Kant, Metaphysik der Sitten. Tugendlehre, A 181. 
blaženosti.“34 Bůh a budoucí blaženost hrají roli pružin, které musíme při vší moralitě předpokládat. ${ }^{35}$ Silnější variantu představuje věta, že „důvod závaznosti“" mravního zákona přece jenom leží v Boží vůli, protože „závazné může být pouze to, co je v souladu s naší blažeností; toto však může vykonat pouze Bůh". ${ }^{36}$ I když Kant ve svých Reflexich rovněž osciluje mezi několika pojetími, nejvíce se kritické pozici blíží, když hovoří o tom, že „očekávání odměny“ umenšuje mravní hodnotu chování, je-li určujícím důvodem vůle. Očekávání posmrtné blaženosti je však mravně v pořádku tehdy, když nám toto očekávání „slouží k tomu, aby byla odstraněna překážka mravnosti, spočívající ve strachu před ztrátou blaženosti““.37 Tato pozice by mohla tvořit zároveň klíč i pro konsistentní interpretaci nejednoznačnosti kritických spisů ohledně subjektivní, ,,pružinové“ síly mravního zákona: Náboženství se svou nadějí na budoucí blaženost pro mravně se chápajícího a o mravnost ve svém chování usilujícího by netvořilo pružinu mravního zákona, nýbrž „posilu pružiny“, která by nám pomáhala žít mravně po celý život.

I když Kant ve své Přednášce o etice - jako v kritických dílech - již rozlišuje mezi antropologií (která se vztahuje na empirického člověka) a morální filosofií (která se zaměřuje na to, co má být), jedním dechem dodává, že morální filosofie samožrejmě (empirickou) antropologii předpokládá. Musíme totiž znát subjekt a vědět, zda je s to konat to, co konat má, tedy co je jeho etickou povinností. ${ }^{38}$ Ve své přednášce rozlišuje Kant mezi principem diiudikace a principem exekuce. Toto rozlišení nenajdeme v Kantem vydaných kritických dílech. Princip diiudikace je „principem pro posouzení“ a týká se otázky: „Jaké jednání je mravně dobré a jaké nikoli“"? ${ }^{39}$ Princip exekuce je oproti tomu ,principem pro vykonání závazného jednání“, který se zabývá otázkou: „Co mě přiměje k tomu, abych podle těchto zákonů žil?"“40 Princip exekuce, tedy uskutečnění toho, co nám mravní zákon přikazuje, je odkázán na znalost „em-

34 I. Kant, Reflexionen, 7279, in: AA XIX, str. 301: „Die moralischen Gesetze haben wohl das principium obligandi in sich, aber obligiren nicht ohne religion, weil sie nicht durch ihre Natur Verheißung der Glückseligkeit bey sich führen."

35 Srv. tamt., 7303, in: $A A$ XIX, str. 307.

36 Srv. tamt., 7258, in: $A A$ XIX, str. 296.

37 Srv. tamt., 7281, in: $A A$ XIX, str. 301.

38 Srv. I. Kant, Eine Vorlesung über Ethik, str. 2 n.

39 Srv. tamt., str. 44; I. Kant, O nejvyšším principu morálky, str. 136.

40 Srv. tamt. Jiří Chotaš používá ve svém překladu pro pojem „Triebfeder“ slovo „pohnutka“. Osobně se zde držím rozlišení a překladu z I. Kant, Základy meta- 
pirického“ člověka, jinak by mravní zákon byl jen krásnou iluzí. Znalost antropologických dat o člověku je nutná pro princip exekuce, ne však pro princip diiudikace. $\mathrm{K}$ antropologické znalosti z pohledu mravnosti patří především otázka subjektivni motivace mravně určené vůle. A zde přichází ke slovu jak „morální pocit“ jako úcta k zákonu, tak i otázka blaženosti, která je zase bytostně spjata s náboženstvím. Kant hledá ve své praktické filosofii odpověd' na dvě otázky: na otázku po nejvyšším mravním principu, po nejvyšším mravním ideálu a zároveň se snaží pojmenovat podmínky, za nichž je možné uskutečnit vlastní subjektivní vůlí to, co je eticky přikazováno. V této souvislosti se Kant ve svých Reflexích vymezuje vůči stoickému či epikurejskému mravnímu pojetí. I když byl Kant jistě především ve své rané filosofii stoicismem ovlivněn, vytýká mu, že nezohledňuje lidskou empirickou přirozenost: „Stoická nauka je nejpravdivější čistá morálka, ale nejméně přiměřená lidské přirozenosti... Stoický ideál je správný čistý ideál mravů, ale nesprávný v ohledu na konkrétní lidskou přirozenost; je správné, že si máme takto počínat, ale mylné, že si nikdy takto počínat nebudeme. “41 Stoikové chybují podle Kanta $\mathrm{v}$ př́lišném spolehnutí se na vlastní ctnost, v němž Kant vidí až pýchu. ${ }^{42}$ Kant zastává názor, že vlastní ctnosti nikdy nedokážeme konečně posoudit, a tudíž na ně ani nemůžeme být hrdi takovým zpo̊sobem jako stoikové. S tím je spojena i skepse k náhledu, že nám vědomí vlastní ctnosti postačuje k dosažení blaženosti. Oboje Kant odmítá. K správné čistotě mravů patří náhled, že nám čistota vlastní mravní motivace zůstává skryta, a tudíž není možné žádné „hrdé“ vědomí ctnosti. A protože člověk ve svém životě nikdy nedosáhne vůle, která by naprosto odpovídala mravnímu zákonu, musí spoléhat na vyšší „instanci“, která „doplní“ to, co člověku chybí. S tím souvisí Kantova představa, že pouhé vědomí správného mravního chování člověku nemůže zaručit blaženost, i kdyby jí byl hoden. S důrazem na empirickou lidskou přirozenost dochází Kant k názoru, že i mravně charakterní člověk zůstává stále bytostí konečnou a potřebnou, a tudíž odkázanou na naplnění své touhy po štěstí, která vposledku dostává podobu naděje na posmrtnou blaženost. V tomto

fyziky mravi̊, str. 46 n.: ,pohnutka“ je překladem německého „Bestimmungsgrund“ a ,pružina“ překladem pojmu „Triebfeder“.

41 I. Kant, Reflexionen, 6607, in: $A A$ XIX, str. 106: „Die stoische Lehre ist die wahrhafteste der reinen Moral, aber am wenigsten der Natur des Menschen angemessen. ... Das stoische Ideal ist das richtigste reine Ideal der Sitten, aber in concreto auf die menschliche Natur unrichtig; es ist richtig, daß man so verfahren soll, aber falsch, daß man jemals so verfahren wird.“

42 Srv. I. Kant, Reflexionen, 7312, in: AA XIX, str. 309. 
ohledu Kant neustále podtrhuje, že jeho koncept praktické filosofie nejvíce konvenuje křest’anské představě o mravnosti. ${ }^{43}$

\section{Mravní zákon jako jediná pohnutka vůle, blaženost a náboženství jako ,nutný doplněk“" mravnosti}

Kant hledá subjektivní pružinu vůle, která má zároveň dostát nároku, aby byla současně i objektivní pohnutkou vůle, kterou představuje mravní zákon. Otázka zní: Jak se objektivní zákon může stát subjektivní pružinou vůle? V Kritice praktického rozumu nalézá Kant takovouto pružinu v morálním citu, který nazývá „úcta k zákonu“: „Morální zákon tedy, tak jako je skrze praktický čistý rozum formální pohnutkou jednání, tak jako je sice i materiální, ale jen objektivní pohnutkou předmětů jednání pod jmény dobra a zla, tak je také subjektivní pohnutkou, tj. pružinou tohoto jednání, jelikož má vliv na mravnost subjektu a vyvolává cit, který by byl zaměřen na moralitu. “44 I když se u „úcty k zákonu“ jedná o cit, není tím myšlen cit smyslový, nýbrž intelektuální. Rozum sám „způsobuje“ tento morální cit, který zaručuje mravnímu zákonu vliv na vůli. „Úcta k zákonu“ tedy není další, přídavnou pružinou k morálnímu zákonu, protože jako morální, intelektuální cit je také působena čistým praktickým rozumem, stejně tak jako mravní zákon. Když tudíž Kant píše, že „úcta k morálnímu zákonu je tedy jedinou a zároveň nepochybnou morální pružinou“ ${ }^{45}$ nestojí tento výrok v protikladu k tezi, že jedinou pružinou vůle v mravním ohledu musí být mravní zákon. Od pohnutky či pružiny je třeba odlišit objekt či předmět čistého praktického rozumu. Tvoří „nejvyšší dobro“ jako předmět čistého praktického rozumu a s ním spojený pojem blaženosti či náboženství ve formě postulátů existence Boha a nesmrtelnosti duše podporující či přídavné pružiny? ${ }^{46}$ Je skutečně mravní zákon dostačující a jedinou pružinou vůle v mravním ohledu? Nejprve je třeba říci, že ačkoliv každé chtění vůle je chtění „něčeho“, tedy že vůle se vždy musí vztahovat k nějakému předmětu či objektu, nemá v Kantově

43 Srv. tamt. nebo např. Reflexionen, 6838, in: AA XIX, str. 176.

44 I. Kant, Kritika praktického rozumu, str. 128 n.; Kritik der praktischen Vernunft, A 133.

45 Tamt., str. 134; A 139.

46 Srv. k tomu např. A. W. Wood, Kant's Moral Religion, New York 2009, str. 38-68. 
pojetí pojem nejvyššího dobra jako předmět rozumu motivační funkci jednání ve smyslu pohnutky.

Vztah mezi předmětem, účelem vůle a jejím morálním určením je velmi dobře osvětlen v díle $O$ obecném rčení: Je-li něco správné v teorii, nemusi se to ještě hodit pro praxi z roku 1793. Kant zde v odpovědi na kritiku Christiana Garveho zdůrazňuje, že víra „v morálního vládce světa a v budoucí život" netvoří nutné předpoklady pro to, aby pojem povinnosti získal ,jistý důvod a potřebnou sílu nějaké pohnutky, nýbrž tím pouze $\mathrm{v}$ onom ideálu čistého rozumu získává i objekt ${ }^{\text {“ }}{ }^{47}$ Povinnost představuje výhradně „omezení vůle na podmínku všeobecného zákonodárství“, přičemž účelem či předmětem vůle pak může být cokoliv, protože je od tohoto předmětu abstrahováno. „Potřeba pokládat za konečný účel všech věcí nejvyšší, a to i naším spolupůsobením dosažitelné dobro není potřebou vyplývající z nedostatku na straně morálních pohnutek, nýbrž na straně vnějších okolností, za nichž pouze může být objekt jakožto účel o sobě (jakožto morální konečný účel) přiměřeně těmto pohnutkám vytvořen. “48 Určení vůle skrze mravní zákon zůstává jedinou pohnutkou vůle, ale mravní povinnost působící na vůli se rozšiřuje o povinnost vytvoření skutečného, morálního světa jako objektu vůle. Je sice možné, že v pojmu nejvyššího dobra, o jehož uskutečnění se má člověk zasadit, je spoluobsažena i vlastní blaženost, ta však nepředstavuje motiv vůle, a tudíž se ani nejedná o zištnou motivaci pod morální rouškou. Motivačně pohnutkové určení vůle v mravním ohledu může podle Kanta spočívat pouze v mravním zákonu: „U člověka proto není pohnutkou, která je přítomna v ideji nejvyššího dobra dosažitelného ve světě jeho spolupůsobením, ani vlastní zamýšlená blaženost, nýbrž pouze tato idea jako účel o sobě, a tedy úsilí o ni jako povinnost. Tato idea totiž neobsahuje naději na blaženost vůbec, nýbrž jen poměr mezi blažeností a důstojností subjektu, at’ už je to subjekt kterýkoli.“49 Ve světle těchto upřesnění ze spisu $O$ obecném rčení snad lze vysvětlit i nejasnost, která se ukázala ve výše zmíněné pasáži z Kritiky čistého rozumu: „Rozumí se však samo sebou, že je-li v pojmu nejvyššího

47 I. Kant, O obecném rčení: Je-li něco správné v teorii, nemusí se ještě hodit pro praxi, in: týž, Studie k dějinám a politice, vyd. M. Sobotka - K. Novotný, přel. J. Loužil - P. Stehlíková - K. Novotný, Praha 2013, str. 70; I. Kant, Über den Gemeinspruch: Das mag in der Theorie richtig sein, taugt aber nicht für die Praxis, in: Werke in zehn Bänden, IX: Schriften zur Anthropologie, Geschichtsphilosophie, Politik und Pädagogik, Darmstadt 1983, A 211.

48 Tamt.

49 I. Kant, O obecném rčení, str. 71, pozn. 4; Über den Gemeinspruch, A 213. 
dobra mravní zákon jako nejvyšší podmínka již spoluobsažen, potom není nejvyšší dobro pouze objektem, nýbrž také jeho pojmem, a představa jeho existence, možné díky našemu praktickému rozumu, je zároveň pohnutkou čisté vůle. "50 I přes jistou nejasnost formulace zde Kant zřjejmě nechce tvrdit, že nejvyšší dobro by mohlo zastávat funkci pohnutky čisté vůle. Nejvyšší dobro je ,pohnutkou“ pouze do té míry, do jaké je v jeho pojmu „spoluobsažen“ mravní zákon jako „nejvyšší podmínka“, samo o sobě však pohnutkou v mravním slova smyslu být nemůže. Nejvyšší dobro tak zůstává objektem či účelem vůle, aniž by vůli v mravním ohledu určovalo jako pohnutka. Morální vůle je tedy určená výhradně mravním zákonem jako pohnutkou a takto již „motivovaná“ vůle si poté vytváří nejvyšší dobro jako svůj předmět.

Problematiku morálního určení vůle v Kantově myšlení lze jistě zkoumat $\mathrm{z}$ různých pozic a $\mathrm{z}$ rozličných perspektiv. Tento článek představuje jednu z nich. Naším cílem bylo na jedné straně představit „konečnou“ kritickou pozici ohledně morálního určení vůle, která klade důraz na mravní zákon jako jedinou pohnutku vůle. Zároveň jsme chtěli ukázat, jakou cestou Kant ke své pozici dochází, a to především v kontextu prací za Kantova života nevydaných. Na druhé straně však i Kantova kritická pozice vykazuje jisté nejasnosti a nepřesné formulace, budící dojem nekonzistentnosti. V této konečné pozici se zrcadlí Kantův vysoký nárok, s nímž chce určit co nejpřísněji rozumový objektivní, praktický mravní zákon a zároveň dostát lidské empirické přirozenosti. I když se nejvyšší morální princip nemůže zakládat na empirické, tedy nahodilé přirozenosti lidské vůle, nebot' musí platit nutně pro všechny rozumné bytosti, přesto je v Kantově myšlení systém morálky jako takový spojen s empirickou antropologií a rozumovým náboženstvím. Přes všechnu zmíněnou problematičnost Kantovy pozice v souvislosti s morálním určením vůle snad lze závěrem říci: Jádrem Kantovy pozice zůstává náhled, že jedinou pohnutkou a pružinou vůle musí být výhradně mravní zákon. Vlastní blaženost obsažená v pojmu nejvyššího dobra a s ním spojené postuláty existence Boha a nesmrtelnosti duše sice nepředstavují pohnutky či pružiny vůle, přesto však tvoří „,nutný doplněk“ systému mravnosti. Bez této podpory mravní motivace ve smyslu odstranění překážek mravnosti v celoživotním úsilí o mravnost není Kantův morální systém myslitelný. ${ }^{51}$

50 I. Kant, Kritika praktického rozumu, str. 188; Kritik der praktischen Vernunft, A 197.

51 Tento článek je výstupem grantového projektu GAČR 16-22881 S „Proměny vztahu etiky a náboženství v díle Immanuela Kanta“. 


\section{ZUSAMMENFASSUNG}

Der Beitrag widmet sich der Problematik der moralischen Bestimmung des Willens in Kants Ethik. Den Ausgangspunkt bildet seine kritische Position, die sich durch ein „rigoristisches Verständnis der Ethik“ auszeichnet: Alleine das objektive Sittengesetz ist als Bestimmungsgrund des Willens ausreichend und zwar auch subjektiv als die Triebfeder des Willens. Aufgrund der Auswertung von Kants Vorträgen über Ethik und Kants Reflexionen zeigt sich, dass seine Position bezüglich der moralischen Bestimmung des Willens doch nicht ganz eindeutig ist und zwar sowohl in seiner vorkritischen Phase, wie auch in seinen kritischen Schriften. Trotz allen Unklarheiten behält jedoch die kritische Position ihre Gültigkeit: Alleine das Moralgesetz bleibt sowohl der Bestimmungsgrund, als auch die Triebfeder des Willens. Die Glückseligkeit und die Religion bilden dann eine „notwendige Ergänzung“ im System der Moralität.

SUMMARY

The article deals with the problem of the moral determination of the will in Kant's ethics. The starting point is the critical position marked by the "rigoristic concept of ethics", i.e. the view that only the objective moral law presents a sufficient determining ground of the will, including subjectively, as an incentive of the will. Based on an examination of Kant's lectures on ethics and Kant's manuscript reflections, it can be shown that his position regarding moral determination of human will is much more ambiguous both in the pre-critical phase and in his critical writings. In spite of this ambiguity, Kant retains his critical position: only the moral law remains both a determining ground and an incentive of the will. Happiness and religion form the "necessary complement" of the system of morality. 